inOedia $\quad \begin{aligned} & \text { InMedia } \\ & \text { The French Journal of Media Studies }\end{aligned}$

6 | 2017

Fields of Dreams and Messages

\title{
Long Shot: The Prospects and Limitations of Sports and Celebrity Athlete Diplomacy
}

Michael K. Park

\section{(2) OpenEdition \\ Journals}

Electronic version

URL: http://journals.openedition.org/inmedia/855

ISSN: 2259-4728

Publisher

Center for Research on the English-Speaking World (CREW)

Electronic reference

Michael K. Park, « Long Shot: The Prospects and Limitations of Sports and Celebrity Athlete

Diplomacy », InMedia [Online], 6 | 2017, Online since 18 December 2017, connection on 08 September 2020. URL : http://journals.openedition.org/inmedia/855

This text was automatically generated on 8 September 2020

(c) InMedia 


\title{
Long Shot: The Prospects and Limitations of Sports and Celebrity Athlete Diplomacy
}

\author{
Michael K. Park
}

\section{Introduction}

1 Avery Brundage, former president of the International Olympics Committee, once stated that, "sports are completely free of politics." ${ }^{1}$ History, however, reveals that sports have long been utilized for diplomatic purposes, including international boycotts, national propaganda, and as a platform to promote civil rights. Sports diplomacy - the mixture of sport, politics and diplomacy - has been viewed as a component of public diplomacy at all levels. ${ }^{2}$ Former Australian foreign minister, Gareth Evans, defined public diplomacy as "an exercise in persuasion and influence that extends beyond traditional diplomacy by leveraging a much larger case of players both inside and outside government." ${ }^{3}$ If public diplomacy describes the means by which states and non-state actors understand cultures, manage relationships, and influence opinions and actions to advance their interests, ${ }^{4}$ than sports diplomacy is one of the many means to those ends. However, not all sports diplomacy occurs through official state channels; individual athletes can also contribute to diplomacy efforts, even when their conduct is "incongruent with that of the diplomatic culture."

While there has been a longstanding history of sports in the diplomatic arena, there has recently been an increased focus on the use and effect of sports and public diplomacy within the context of foreign policy. Recent scholarship on sports diplomacy has included an analysis of sports as a tool for foreign diplomacy; ${ }^{6}$ a taxonomy for understanding how international sports and diplomacy interact; ${ }^{7}$ an examination of the limitations of organized sport as an instrument of diplomacy; and the public diplomacy opportunities with sporting mega-events. ${ }^{9}$ However, there is very little scholarship exploring the role of celebrity athletes in either public diplomacy or 
through non-state sanctioned channels of engagement. While celebrity diplomats such as U2's Bono and actor George Clooney have been the subject of great attention for their influence on international affairs, celebrity athletes, including non-state actors of sport can also be effective diplomacy instruments as part of a nation's soft power-which Nye defined as the ability to persuade and influence others through the attraction of a nation's values and culture. ${ }^{10}$

Informed by Cooper's ${ }^{11}$ theoretical perspective on celebrity diplomacy, this work aims to extend the discourse into the area of sports celebrities and explores the unique features of celebrity athletes as an instrument of diplomacy. This work is also informed by Vanc's $\mathrm{s}^{12}$ work on celebrity athletes as non-state sanctioned antidiplomats, and critically evaluates Dennis Rodman's "basketball diplomacy" efforts in North Korea ("DPRK") as a case study to demonstrate the unique power sports celebrity diplomacy can have toward engagement with even the most reclusive and hostile governments. The regime's tight restrictions on Western culture, and the fact that cultural invitations and exchanges are so extremely rare, make Rodman's "basketball diplomacy" efforts particularly significant as a site for critical evaluation. Moreover, this works examines North Korean media accounts of Rodman's basketball diplomacy and draws on Korean Central News Agency (KCNA) reports from the 2013 calendar year for a textual analysis of KCNA's reporting of Rodman's "basketball diplomacy." As a state-controlled media outlet, KCNA reports are ideological, and any reports that covered Rodman's visits will be analyzed to uncover on how the state-run media contextualized these visits from the DRPK's perspective. Finally, this analysis sheds light on the potential limitations of sports celebrity diplomacy, and offers cautious conclusions when celebrity athletes are used as instruments of engagement.

This paper begins by providing historical context to the volatile geopolitical relations on the Korean peninsula. Since the end of the Korean War, relations between the U.S. and North Korea have been fraught with military tension, and nuclear threats from the North, yet traditional hard power resources has had a de minimus impact in thwarting the regime's nuclear ambitions and irrational behavior. In order to fully understand the potential value and attraction of sport and celebrity athlete diplomacy to a regime such as the DPRK, a review of the globalization of sport and celebrity athlete at the intersection of communication technology and transnational consumption must be taken into consideration. In order to contextualize sports celebrity diplomacy within the fields of sports and celebrity diplomacy, a review of the emerging field of sports diplomacy scholarship and celebrity diplomacy studies then follows, before an analysis of a case study involving sports celebrity diplomacy.

\section{U.S. - D.P.R.K.: Hard Power Relations}

Korea has been a divided country since the end of WWII, when the Japanese ended its occupation of the country. At the end of the war, the Soviet Union had stationed troops in Manchuria and northern Korea, and after considering the military and geopolitical implications a Soviet occupation of the peninsula could have on the region, the U.S. had to quickly decide on a post-Japanese occupation plan in Korea. The U.S. subsequently demarcated Korea at the thirty-eighth parallel; U.S. troops would occupy the area south of the parallel, while Soviet troops would occupy the north. The Soviet Union appointed a Korean guerilla commander, Kim Il-Sung, to head its regime in the North, 
and his rule lasted until his death in 1994, when his son Kim Jong-Il succeeded him. In June of 1950, North Korea, backed by the Soviets and Chinese, invaded the U.S.-backed South in an effort to unify the country, leading to the three-year Korean War that ended with an armistice agreement in July, 1953; to date, no official peace treaty has ever been signed.

6 For more than half a century since the Korean War, the North Korean regime has been marked by bizarre-perhaps calculated-behavior on the international front, including acts of terrorism, and continued efforts toward nuclearization. Moreover, since the end of the Cold War and disintegration of the Soviet bloc, North Korea's economy has imploded, and most of the nation's public has slid into a state of severe deprivation. Relations between the U.S. and the D.P.R.K. have historically been defined with the use of hard power resources-threats of military force, economic sanctions and limited humanitarian aid. The U.S. and the DPRK have no formal diplomatic relations, and since the 1980s, limited engagement between the U.S. and North Korea have been centered on the security threats posed by the North's pursuit of nuclear armament. As Victor Cha aptly notes, the world has witnessed reruns of the same nuclear crisis-a North Korean version of Groundhog Day-that begins with international atomic inspectors declaring the North is in violation of the Non-Proliferation Treaty (NPT); North threatens withdrawal from the NPT; the U.S. and United Nations condemn and sanction the DPRK; the DPRK retaliates with further efforts to produce nuclear weapons. ${ }^{13}$

7 After Kim Jong-Il's death in late 2011, his youngest son, Kim Jong-un (KJU), was declared the "supreme leader" of the hermetic nation. ${ }^{14}$ Unlike KJU, the political and ideological aspirations of his father were relatively clear. Kim Jong-Il was concerned about securing a peace treaty as it would guarantee the sovereignty of the DPRK, and was also concerned with garnering respect through recognition of its legitimacy. ${ }^{15}$ In fact, a visit to North Korea by the President of the United States was highly coveted by the former ruler because in the regime's view, it would end its "pariah status" and be tangible acceptance of its legitimacy for the world to see. ${ }^{16}$

Much less is known about KJU's ideological proclivities. While the regime's recent missile tests and threatening rhetoric mirror the policies and destabilizing actions of the past, there is also some evidence that KJU may be more receptive to Western cultural engagement. As a young student, KJU was enamored with icons of American popular culture, including American sport: he often wore Nike Air Jordans, and spent hours doing drawings of Michael Jordan, whom he "worshipped." ${ }^{17}$ There is also an increasing number of Western products that have entered the reclusive nation, from mobile phones and Adidas shoes to Kentucky whiskey. ${ }^{18}$ Even Disney characters have infiltrated the regime's highest levels of leadership; costumed versions of famous Disney characters were prominently featured at a gala in honor of KJU's ascendance as the "supreme leader." ${ }^{19}$ Where hard power means may fall short, perhaps there is room for the soft power of sport and celebrity to offer an effective channel towards further engagement.

\section{The Soft Power of Sport: Attraction and Consumption}

Known as "The Worm" during his colorful National Basketball Association (NBA) career (both on and off the court), Dennis Rodman was an athlete whose aggressiveness and 
combative nature propelled him to All-Star status in the NBA, where he won several championships, including three with the Chicago Bulls. So after a post-NBA career that included "professional" wrestling and serving as commissioner of the Lingerie Football League, how did this public figure worm his way into foreign affairs and become the highest-profile American to meet with Kim Jong Un (KJU), the young leader of North Korea-a country the U.S. has no formal diplomatic relations with? Dubbed "basketball diplomacy" by the media, the meeting was the result of arrangements made between two private media entities, Vice media and HBO, and the North Korean regime. Vice media's footage revealed a head of state clearly "star-struck" with Rodman's presence and the celebrity athlete's appeal and reception by the secretive regime is a reminder of how attractive a nation's cultural products-as a form of soft power-can be.

Although soft power is broadly understood as the ability to shape the preferences of others and align them to your own through the attraction of culture and values, the concept has largely escaped definitional consensus: what exactly constitutes soft power?

Joseph Nye defined soft power as the ability to influence others by attraction and persuasion. ${ }^{20}$ It involves strategies of co-opting rather than coercion by harnessing "intangible resources such as culture, ideology, and institutions." ${ }^{21}$ While the concept was originally in reference to American foreign policy strategy, Nye's concept has gained political and academic currency around the world. ${ }^{22}$ However, the concept has been labeled as "confusing" 23 since it can be argued that a nation's foreign policy is the mere manifestation of its hard power, and core values and domestic institutions are integral to a public's culture. Informed by Fan's approach to the concept, this author holds soft power synonymous with cultural power. ${ }^{24}$ As Nye points out, "[m]uch of American soft power has been produced by Hollywood, Harvard, Microsoft, and Michael Jordan." ${ }^{25}$ Culture can be transmitted in many ways, including the ideas and values America exports into the minds of more than half a million foreign students who study in U.S. universities every year. ${ }^{26}$ Although the U.S. is a leading site for intellectual and academic exchange, other countries have also taken advantage of soft power forms of cultural exchange, even exchanges with reclusive states. For instance, Canada and North Korea have a knowledge-sharing program where North Korean scholars visit Canada and gain access to desired knowledge and ideas on business and economics. ${ }^{27}$

Nye suggests that attraction is more than persuasion through rational argument, but is also the output of affect and feelings. ${ }^{28}$ The attraction of soft power may also relate to the fulfillment of needs; it may be based on both or either rational and affective components of culture, values, and/or policies. ${ }^{29}$ Furthermore, culture can also be transmitted through commerce and the export of cultural products such as entertainment and sports media through their long-arm transnational reach, which today, are frequently co-productions between the state and private civil actors. Soft power may also appeal to individuals and collective non-state actors, in contrast to hard power, which the government primarily controls through military and economic policies. ${ }^{30}$ As Bially Mattern notes, "soft power is available to any actor that can render itself attractive to another." ${ }^{31}$ Furthermore, Nye notes that advanced digital communication platforms has enabled greater scrutiny of states' actions, and the use of force has become less tolerated in post-industrial societies, leading to the increasing significance of soft forms of power. ${ }^{32}$ 
ernments, transnational corporations, and private actors continue to tap into the potential of sport as a soft power resource, whether to promote ideological superiority or to promote culture abroad. Within this context, sport has become "inextricably linked to a multidimensional matrix of cultural, economic, environmental and political spheres in contemporary social life." ${ }^{33}$ Nike's Phil Knight once proclaimed, "sports has become the dominant entertainment of the world." ${ }^{34}$ Regardless of national origin or religious orientation: who doesn't like sports? In reference to a historic 2015 match between the New York Cosmos soccer team and the Cuban national squad, U.S. Congressman Charles Rangel noted that such events are bringing people together more so than presidents and professional diplomats, "because nothing stops sports fans from enjoying their sports." ${ }^{35}$ The global appeal of sports is evidenced by the fact that there are currently over 203 national Olympic committees in the International Olympic Committee, which represents eleven more countries than there are national members of the United Nations. ${ }^{36}$ If sports were a religion, most of the world's population would be fervent followers of it. Redeker notes that sports "conjoin the idea of Empire and the idea of the Church, together in the universality and the government of souls." ${ }^{37}$

According to Walter LaFeber, transnational capitalists such as Phil Knight of Nike and media magnate Ted Turner enabled American media and popular culture to spread across the globe in the late $20^{\text {th }}$ century. ${ }^{38}$ At the turn of the millennium, American soft power also benefitted from widespread adoption and use of the English language and the global influence of U.S. media products-nearly 80 percent of Europe's television programs originated in the U.S. ${ }^{39}$ One of the most pronounced iterations of U.S. soft power in the late twentieth-century was the international popularity of Michael Jordan and his association with Nike-a symbiotic commercial alliance that took hold of the global cultural imaginary. The proliferation of direct-broadcast satellites (DBS) and the budding development of digital media in the 1980s-90s helped turn Michael Jordan into a global icon; he was a brand to be consumed and a promoter of consumptionparticularly with products associated with "His Airness"-including Nike, his most lucrative corporate sponsor. LaFeber notes that Jordan's rise to become the global commercial ideal was fueled by Nike's massive global advertising campaigns and heavy foreign investment in growing markets like China. ${ }^{40}$ Global-based advertising increased as Jordan's athletic accomplishments reached its zenith at the end of the twentieth century. In 1980, the average consumer was exposed to sixteen hundred advertising messages a day; a decade later, it was about three thousand. ${ }^{41}$ Jordan was also the perfect embodiment of the sports spectacle, transforming sports into "a forum that sells the values, products, celebrities, and institutions of the media and consumer society." ${ }^{42}$

15 Jordan's global appeal aligned with and benefitted from the dynamic forces of American dominated-media, U.S. advertising techniques and the ability of the N.B.A. to penetrate other cultures. ${ }^{43}$ As LaFeber points out, "U.S. culture changed other cultures more than those cultures changed how Americans lived, thought, and spent their leisure time. ${ }^{{ }^{44}}$ However, the global commercial success of Nike, the N.B.A., and Michael Jordan did not arrive without moral concerns and charges that this U.S.-based sports/ media expansion was part of a new post-industrial wave of cultural imperialism. Threats of "Americanization" have long simmered throughout the globe, but as LaFeber points out, it had taken on a new powerful form with the advent of communication 
satellites and cable, tethered with marketing machines that used sports to promote advertising and the consumption of transnational goods. ${ }^{45}$

The attraction of American popular culture continues to run deep. American media and communication technology (e.g. Apple, Facebook) remain the most popular around the globe, and after measuring ratings across five continents, CBS's "CSI: Crime Scene Investigation" was named as "the most watched TV show in the world in 2012." ${ }^{46}$ In 2014, Paramount's Transformers: Age of Extinction became China's top-grossing film of all time, earning over $\$ 300$ million, less than a month after the film's release. ${ }^{47}$ Thanks in part to the NBA's global push, spearheaded by Michael Jordan's awe-inspiring performances of the 1990s and the transnational corporatization of sport (e.g. Nike), basketball has increasingly become a universal language understood and admired around the globe. American basketball today has arguably become one of the most influential soft power resources for the U.S. as evidenced by the fact that the world's most populated country - China - has an insatiable appetite for American basketball. The NBA averages five million viewers a game in China for its television broadcasts, three million more than for U.S. cable broadcasts in 2013. ${ }^{48}$ Moreover, the "Association" has 80 million followers on its Chinese social media accounts, making it the most popular sports league in China. ${ }^{49}$ Although the most popular sports teams on social media overwhelmingly include soccer teams, three of the top fourteen include N.B.A. teams, including the Los Angeles Lakers and Chicago Bulls. ${ }^{50}$

\section{Sports Diplomacy: A Brief Taxonomy}

17 Although public diplomacy has several meanings, this paper adopts the view that it describes the ways by which states and non-state actors understand cultures, attitudes, and behavior; build and manage relationships; and influence opinions and actions to advance their interests. ${ }^{51}$ It can be understood as failing within categories of cultural exchanges, cultural diplomacy and comprises of continuum of activities that extends from state-driven diplomacy to privately-driven intercultural relations. ${ }^{52}$ Sports diplomacy, as a form of public diplomacy, is thus a unique soft power tool for the spread of a nation's cultural and political influence by exploiting the universal appeal of sports. Murray and Pigman point out two distinct categories of sports diplomacy: international sport as a diplomatic instrument and international-sport-as-diplomacy..$^{53}$

18 The first category involves governments using sport as a tool for carrying out public diplomacy. According to Murray, sports diplomacy "involves representative and diplomatic activities undertaken by sports people on behalf of and in conjunction with their governments. ${ }^{54}$ It is a practice that uses athletes and sporting events to engage, inform, and create a favorable image among the international community pursuant to achieving foreign policy objectives. ${ }^{55}$ Participation in international sport exchanges, hosting global sporting events, and achieving international sporting acclaim, are commonly utilized by states in the pursuit of diplomatic objectives. Although sporting events often appear apolitical, they often serve as political and cultural functions, promoting a nation's values and interests. As Redeker aptly notes, "sports are utilized to increase the imaginary power of the state." ${ }^{56}$

19 An early example of sports diplomacy creating a "dialogue between states" is the oftencited "ping pong" diplomacy of the 1970s, in which table tennis matches between China and U.S. led to formal discussions and increased diplomatic relations. More recently, 
the U.S. State Department's SportsUnited initiative is illustrative of this type of statesponsored public engagement through the diplomatic vehicle of sport. As part of a "diamond diplomacy" initiative, several professional baseball players travel to countries like Columbia and Panama to connect with the youth and promote American ideals, along with highlighting opportunities to study in the U.S. ${ }^{57}$ This form of statesponsored interaction with foreign publics-where governments deliberately employ sport-provides an important platform to export a nation's values and ideas in to the minds of foreign publics, especially to the non-elite public.

Grix \& Houlihan investigated how countries are increasingly using the hosting of sports mega-events as part of their "soft power" strategies to successfully alter their image among "foreign publics." ${ }^{8}$ Sporting mega events like the FIFA World Cup are sites replete with political and social undertones, including collective identity, ideas of citizenship and democratic values. Emerging economies such as Qatar, host of the 2022 FIFA World Cup, have aggressively used the vehicle of international sport to accelerate their entry to, and acceptance within the world's mature economies. Through the creation of sporting "academies" around the world, in addition to participating in and hosting international sports events, Qatar has been at the forefront of nation building through sport; a form of nation branding that is tied to how positively people perceive the cultural and political assets of a nation. Such sites are therefore important spaces for mutual exchange and dialogue, and where the countries can project an idealized image of their nation. For instance, China has used international sporting competition to project cultural power and as an instrument to counter the "stereotype of the weak and diminutive Chinese and show how China can compete against the best in the world." ${ }^{59}$ Even the reclusive nation of North Korea established a state sports and culture commission in 2012, and has subsequently devoted a large amount of resources to develop elite sporting facilities and training programs with goal of becoming a "sports powerhouse." 60

21 The second category of sports diplomacy-international-sport-as-diplomacy-is "less transparent and more elusive than the first." ${ }^{61}$ This category includes both the effects of international sport on diplomacy and the specialized diplomacy of international sport. ${ }^{62}$ In contrast to nation states employing sport as an instrument of public diplomacy, most international sport competition is generally void of any diplomatic purpose; international sporting competition, however, 'serves as a form of diplomacy in its own right." ${ }^{63}$ The effects of international sport on diplomacy refer to how international sport has direct effects upon diplomatic relations between governments and publics. Murray and Pigman refer to large sporting events, such as the Olympic games, and the impact such an event has on the global public's imaginary-that "international cooperation is both possible and positive." ${ }^{64}$ The specialized diplomacy of international sport refers the multi-actor diplomatic representation and communication that must occur before large sporting events take place. Thus, in order to produce large sporting events and pursue their objectives, international sporting bodies must engage in diplomatic representation and negotiation with several state and non-state actors. ${ }^{65}$

As Giulianotti and Robertson note, the participation of national sport teams in international sports events is highly important in political and symbolic terms and for imagining how the nation is seen across the world. ${ }^{66}$ Global public perceptions and opinions of nations are often developed by both sporting performance and representation in the international arena. A compelling narrative in the sporting arena 
can be an impactful soft power resource as "people may be drawn to certain actors, events, and explanations that describe the history of a country, or the specifics of a policy." ${ }^{67}$ One recent example of the effects of international sport on diplomacy can be seen with the U.S. men's national soccer team (USMNT) in the 2014 FIFA World Cup in Brazil. The USMNT included several players with mixed-racial heritage, most of whom were born outside the U.S. Players like Jermaine Jones, John Brooks, Fabian Johnson, Danny Williams and Julian Green are sons of American servicemen and German mothers, and they spent almost their entire lives outside the U.S.

For several of the players, the decision to play for the U.S. as opposed to Germany related to their racial identities. Midfielder Danny Williams publicly expressed his observation that the U.S. has a large number of mixed-race individuals and as a person of mixed-race heritage, he felt "more normal" in the U.S. and "more American than German." ${ }^{8}$ Commenting on the issue of race in Germany, Williams stated, "when people look at me in Germany, they know I am not 100\% German." ${ }^{69}$ Williams's comments reflect one popular perception of America: the U.S. as an inclusive public driven by its immigrant heritage and a nation that values diversity of national origin. The effects of the representational diversity of the squad, with its immigrant roots and multi-national character, can therefore amplify American values to the world, albeit an idealized image of the nation and society. Soccer is commonly labeled a "game for immigrants," and it is perhaps fitting that the U.S. team was made up of several immigrants-representing a nation full of them-in one of the world's most popular sporting events.

However, sports diplomacy continues to occupy a somewhat dubious standing within the realm of politics and international relations. As a cultural site and practice, sport is viewed in a "schizophrenic" way: "sport is considered both serious and important but insignificant and trivial at different times, in different contexts and by people representing different interest groups." ${ }^{\prime 0}$ As Manzenreiter points out, the efficacy of these sporting platforms on foreign relations are difficult to control; meaning is never uncontested in a "global theatre of representation." ${ }^{11}$ One of the earliest iterations of American sports diplomacy underscores this point. The 1934 Babe Ruth-led AllAmerican baseball tour of Japan began as a goodwill exchange between two nations on the precipice of war. The two nations shared a love of baseball, and Ruth and his teammates played in twelve different cities throughout Japan. Baseball player Connie Mack publicly summed up the tour's "success" stating that the trip did "more for the better understanding between Japanese and Americans than all the diplomatic exchanges ever accomplished." "72 Yet Japan was showing signs of a growing nationalist and military agenda, and several weeks after the ballplayers departed to return home, Japan pulled out of the Washington Naval Treaty, which had limited the size of the navies among the major powers. ${ }^{73}$ After the bombing of Pearl Harbor, instead of chanting "Banzai Babe Ruth," Japanese soldiers could be heard yelling "to Hell with Babe Ruth!" 74

Although often perceived as purely entertainment and recreation, sports continue to play a significant role in the relations between nations. While political relations between two nations are often defined by numerous military conflicts and violence, sports can provide a platform for countries to come out of isolation and take a first step toward international engagement. For instance, the cricket rivalry between India and Pakistan is one of the world's most popular sporting events, and the matches have 
offered opportunities for "cricket diplomacy" by allowing heads of state to exchange visits. More recently, Britain's Prince William visited China and used the sport of soccer to improve diplomatic relations between the two nations by taking part in a soccer clinic where he reached out to the country's President, Xi Jinping, telling him: "I also gather you're quite a football fan." ${ }^{75}$ Moreover, participants in sports diplomacy are no longer limited to state-sponsored actors or the formal diplomatic corps. The modern global network society has enabled new actors in diplomacy to arise, including nongovernmental organizations and individual non-state actors, such as sports celebrities.

\section{The Cult of Celebrity and Sports Celebrity Diplomacy} changing, with non-state transnational actors increasingly playing an influential role in promoting peace, development and how diplomacy operates. Today, mass media has facilitated a dramatic expansion of the sites and means by which sport and celebrity athletes can be both consumed and created. The prevalence and continued influence of celebrity culture reflects global society's addiction to the "cult of celebrity" and the diverse ways that celebrities are promoted. Celebrities, including celebrity athletes, represent the paradox of being simultaneously ordinary and extraordinary, easily consumed by media, but also remote. ${ }^{76}$ Daniel Boorstin's seminal work on celebrity highlighted the increased prevalence of celebrity in modern society, which he argued led to the decline in public figures with "heroic" qualities. ${ }^{77}$ According to Boorstin, the media plays a major role in artificially manufacturing public figures or "human pseudoevents"-individuals who are "well-known for their well-knownness." knownness" and the media attention it commands, however, that can act as a lightning rod for political and social issues, and bring public attention to them.

Celebrity diplomacy is also an outgrowth of the communications revolution and as Murray points out, where the state and its diplomats have floundered, "non-state actors have stepped in and proliferated, neatly filing the partial vacuum of responsibility of the state." 79 According to Cooper, celebrity diplomats are individuals that not only possess ample communications skills, a sense of mission and global reach, but enter the official diplomatic world "and operate through the matrix of complex relationships with state officials." ${ }^{80}$ Moreover, celebrity diplomacy highlights the adaptive quality of diplomacy; as more celebrities become active in transnational policy making, the political elite also use celebrities to enhance their own credibility. ${ }^{81} \mathrm{As}$ opinion leaders, celebrities also "have the power to frame issues in a manner that attracts visibility and new channels of communication at the mass as well as the elite levels." ${ }^{2}$ Non-state actors have also increasingly played an integral role in reconciliation work. For instance, Canada identifies a wide spectrum of public diplomats, including artists, teachers, students, researchers and athletes in addition to professional diplomats..$^{83}$ Often referred to as "Track II" diplomacy, these non-state actors range from "the messianic to the mad and have affected change to the international relations systems." ${ }^{14}$ However, the impact of individual actors who are not agents of state authority have received scant scholarly attention.

The study of public figures engaged in diplomacy tends to focus primarily on issues of activism rather than diplomacy. As Cooper notes, celebrity diplomats have no formal training, communicate in a colloquial and undiplomatic manner, and deliver messages 
to the public via old and new media forms and through mass performances via staged events. ${ }^{85}$ But celebrity diplomats are not limited by formal diplomatic culture; celebrities can go "off-script" and generate controversy through provocative declarations and actions. According to Cooper, celebrity diplomats can be classified into several categories: those with official roles, such as professional diplomats accorded celebrity status such as Bill Clinton and Henry Kissinger, and unofficial roles, such as opinion leaders who advocate or enter activist arenas such as Bono's Red campaign and George Clooney's work on Darfur. ${ }^{86}$ But this is not an exhaustive list, and in the age of social media where private figures can easily morph into online public figures, the scope of public diplomacy can cast a wider net of players both inside and outside government. Everyone has the potential to be an authentic diplomat and "some celebrities deserve to be included as diplomats on their own merit." ${ }^{87}$ As Cooper notes, celebrities hail from many different sources, including "true" Hollywood stars, as well as musical stars, and thus the eligible pool of celebrity diplomats must be broadened..$^{88}$

While sport has been used a tool for carrying out public diplomacy, the role and influence of sports celebrities in the sports diplomacy arena has largely gone unexplored. Due to their athletic prominence, celebrity athletes embody cosmopolitanism and global citizenship and thus attract visibility and media attention. ${ }^{89}$ But greater media scrutiny also comes with a price. Pigman notes that successful diplomacy requires that players be "PD ambassadors in every respect, in that intense media scrutiny means that their lives off the pitch/court/field are on view just as much as their competitive lives." ${ }^{\prime 0}$ However, unlike public figures of film and television fame, celebrity athletes are cloaked in a veneer of authenticity and earned acclaim. Sports stars embody the hero with intrinsic value, who is distinguished by their achievements gained through skill and hard work. Through the meritocratic space of athletic competition, a private figure can gain international recognition based on individual merit. Sport offers a forum of "real individuals participating in unpredictable contests" ${ }^{91}$ and their athletic achievements "elevates them to unique standing in the eyes of their domestic and international fans." ${ }^{92}$ In other words, celebrity athletes have to prove they are worthy of public distinction, which sets celebrity athletes apart from what Boorstin described as a manufactured public figure, or "human pseudo-event." ${ }_{33}$

Celebrity athletes are also key to the imaginary, and the fact that athletes like Lionel Messi, Cristiano Ronaldo and Lebron James are some of the most popular public figures today is "an example of this authority of sport over souls, of its spiritual power." 94 Therefore, while modern celebrities in entertainment are often viewed as exemplars of an "illusory" world of manufactured characters, sporting achievements carry an authenticity that resonates with citizens around the globe. While governments have increasingly engaged in sports diplomacy for the purposes of nation branding, celebrity athletes can also contribute to a country's diplomacy efforts even when the athletes' involvement is not a direct result of formal diplomatic engagement.

31 However, unofficial celebrity diplomacy can also run counter to traditional modes of diplomacy. Antidiplomats, as Cooper argues, are celebrities who run counter to traditional modes and qualities of diplomatic culture, which include (1) physical attributes judged to be salient in diplomacy; (2) cautious use of language, to allow plenty of room for interpretation; and (3) a calm tone, with the ability to lower the temperature of debate. ${ }^{95}$ For instance, Cooper cites music singer and activist Bob Geldof as the antidiplomat archetype, based on Geldof's behavior and actions against the 
qualities of traditional diplomatic culture with regard to image, and language. ${ }^{96}$ Vanc's work on controversial celebrity athletes as "antidiplomats" highlights the ability of such actors to transcend estranged relations through their visibility, "as they draw attention to themselves, their countries and sports through their high media profile." 97 Vanc examined how the constant media coverage of Ilie Nastase's controversial behavior and achievements on and off the court enabled Nastase to significantly contribute to Romania's public diplomacy and the nation's image. ${ }^{98}$ By employing Cooper's theoretical view on celebrity diplomacy to sports, Vanc's work exposed how celebrity athletes as antidiplomats could bring diplomacy benefits to their respective nations..$^{99}$

Informed by Cooper and Vanc's work on celebrity diplomacy, the following section turns to an analysis of Dennis Rodman's visits to the DPRK as a case study to examine the attraction and influence sports celebrity diplomacy can have toward fostering diplomatic engagement. The following analysis will focus particularly on Rodman's first visit in 2013 (February). While Rodman's first visit was subject to intense global media coverage, and a large North Korean public audience, his subsequent visits received much less media fanfare and access to KJU. Rodman's second visit in September 2013 was considered a "low key" private affair spent with KJU and his family; his December visit was intended to train North Korean basketball players, but he never met with KJU. ${ }^{100}$ There is also an important caveat: sports diplomacy, in its various forms and potential for diplomatic engagement, is not always a unilateral exercise of soft power. It can serve the interests of a ruling party or authoritarian regime-turning from meaningful engagement to co-opted media spectacle-limiting the influence of one's cultural capital. It is with this premise that the analysis of the case study proceeds.

\section{From Ping-Pong Diplomacy to Basketball Diplomacy: A Case Study}

Rodman's first visit to the DPRK in February 2013, dubbed "basketball diplomacy" by Vice Media and Rodman himself, involved several non-state actors, including corporate media (Vice, HBO), former American professional basketball players, and a Hall of Fame sports celebrity. Together, this production used both sport and media spectacle to explore the potential for cultural exchange through sport and to film a segment of HBO's television program called "Vice." According to Rodman, his basketball diplomacy visits were meant to exploit his "inside track" with the regime in order to "bridge the gap" toward further engagement. ${ }^{101} \mathrm{He}$ added, "[o]n the subject of the game, I hope it will open doors a little bit around the world." 102 Reflecting on his attempts at "diplomacy," Rodman added: "[s]ports is the one thing on the planet that could actually heal things at least for a day, two days or a week." ${ }^{103}$

However, the popular consensus regarding Rodman's early 2013 visit to North Korea has been read as a way of "producing a television show whose premise is the display of the exotic, bizarre and extreme." ${ }^{104}$ A less likely "sports ambassador" for the global public is inconceivable; Rodman meets all the attributes of an antidiplomat, with his bizarre behavior both on and off the court, to his provocative declarations in public. After his first visit, where Rodman had considerable personal interaction with KJU, Rodman gushed that KJU "is like his grandfather and father, who are great leaders"; he later added that he "loved" the current dictator, and "[t]he guy's really awesome." 105 
While Rodman has been publicly vilified for his visits to the DPRK and his provocative statements, a further examination of his unprecedented access to the North Korean ruler-one of the few Americans to have done so since KJU assumed power-reflects the reach of American soft power, via the attraction of sport and the sports celebrity. While Eric Schmidt, the Executive Chairman of Google, was unable to meet with KJU during a visit to the DPRK shortly before Rodman's arrival Rodman's reception by the regime as an honored guest and his intimate access with KJU speaks volumes about the reach of the soft power of sport, even with sporting figures as controversial as Rodman. ${ }^{106}$

Aside from international relations scholars and diplomacy professionals, most of the general public is unaware that KJU's father, Kim Jong-il (Kim), was a voracious consumer of Hollywood films, the N.B.A., and a "student (scholar?) of cinema." Paul Fischer notes that Kim Jong-il was not particularly astute in economics, bureaucracy or military leadership; but what Kim did have was a sense of "showmanship, of mythmaking and its power. All of which he learned not by studying politics, religion, or history" but from what he "learned from the movies." ${ }^{107}$ Kim's fascination with Western (mostly Hollywood) cinema motivated him to create an international bootlegging network whereby North Korean embassies were directed to "borrow" reels of the newest films and smuggle copies into North Korea. ${ }^{108}$ The dictator's obsession with cinema and its ideological power led him to even kidnap South Korea's most famous film director and actress in 1978, for the purposes of producing films for the North Korean regime. ${ }^{109}$ To cement his "credentials" as an ideological film theorist, Kim Jongil also authored a book on cinematic art entitled, On the Art of Cinema, published in 1973.

It has also been well documented that $\mathrm{KJU}$ and his father also shared a fanaticism with American basketball, particularly with Michael Jordan and the Chicago Bulls-a team that Rodman also played and won championships for. In the 1990s, Kim Jong-Il amassed a large video library of Michael Jordan-led Chicago Bulls games. ${ }^{110}$ Tony Ronzone, director of player personnel for the Dallas Mavericks, who has made several trips to North Korea to conduct clinics, recounted Kim's obsession with basketball: "He's a huge fan. He's addicted to it." 111 In 2000, former U.S. Secretary of State Madeline Albright visited North Korea and presented Kim Jong-Il with a very personal gift: an N.B.A. basketball autographed by Michael Jordan. "His Airness" was subsequently approached about a goodwill trip to the DPRK; Jordan however, declined the request. As a teenager, $\mathrm{KJU}$ openly shared his fanatical interest in basketball, showing up to his Swiss boarding school wearing the most expensive Nike Air Jordan sneakers and a passion for the Chicago Bulls and Los Angeles Lakers. ${ }^{112}$

While Kim Jong-Il and KJU both harbored a strong fascination with American cultural products, the regime has rarely welcomed cultural exchanges, sports or otherwise with the U.S. One notable departure from anti-American cultural policies was a 2008 invitation to the New York Philharmonic. The Philharmonic's 2008 visit and concert in North Korea was the first time an American cultural organization had appeared in the country, and the largest contingent of U.S. citizens to appear since the Korean War. ${ }^{113}$ Interestingly, the country's leader, Kim Jong-Il, did not attend the concert. In contrast, Rodman's "basketball diplomacy" visits were treated like high-level dignitary meetings between heads of state, with KJU publicly sitting next to Rodman and later hosting him with a royal dinner feast. Rodman had achieved unprecedented access to the new 
leader of the DPRK, even without official state capacity, evidencing the attraction and value of the celebrity athlete.

\section{The Contested Terrain of Sports Celebrity Diplomacy}

opportunities for the regime to establish a sense of international legitimacy and domestic propaganda. Bill Clinton's 2009 visit to North Korea as a "private" envoy to help free two American journalists was met by the regime with the fanfare of a state visit. Several images of Kim Jong-Il and Bill Clinton were broadcast to the public through the Korean Central News Agency (KCNA), North Korea's state-run news agency; as one journalist notes, several of the images include backgrounds deliberately selected as a form of "totalitarian kitsch" with one purpose: to bolster a dictatorial regime and glorify its leader. ${ }^{117}$ To further promote the "supreme leader" as a figure to be revered, the KCNA reported that "Clinton expressed words of sincere apology to Kim Jong Il for the hostile acts committed by the two American journalists ... [and] conveyed to Kim Jong Il an earnest request of the U.S. government to leniently pardon them." ${ }^{118}$

41 An analysis of KCNA news reports covering Rodman's 2013 visits also reveals how such "pseudo-events" are contextualized in the service of the state to extend social control through media spectacle. A February 2013 KCNA news report dedicates its entire story on Rodman and his fellow basketball players' visits to a mausoleum and statues of the 
late Kim Il Sung and general secretary Kim Jong Il, where they reportedly "paid high tribute" and "homage to them." 119 Moreover, a September 2013 KCNA report contextualizes Rodman's second visit with KJU to further foster a personality cult, asserting how "grateful" Rodman is to the "broad-minded, supreme leader" for his hospitality, which represents "an expression of good faith toward Americans." ${ }^{120}$ These reports from the North Korean state-run media evince authoritarian-style grandstanding, and like his father before him, $\mathrm{KJU}$ appeared to use this sports event to bolster his own standing as the "supreme leader" and project an image of one who is' internationally respected.

While this effort in "basketball diplomacy" reveals the limitations of sport as a soft power resource-including the opportunity to exploit a sports/media spectacle for the ideological needs of the regime-the showcase of U.S. basketball players also offers an alternative discourse to misconceptions that prolong tension between the two nations.

Furthermore, this effort in sports diplomacy also exposes the secluded North Korean public to American culture and actual Americans in a goodwill environment, distorting the narrative of the U.S. as a lurking and cultural threat. Although it is highly unlikely that Rodman or even Michael Jordan could convince KJU to dismantle his country's quest for a nuclear arsenal, Kim and KJU's fascination with American basketball is indicative of how sports and sports celebrities still transcend borders and culturescelebrity athletes are admired around the world-and many of them, like Rodman, are American public figures.

One journalist pointed out that Rodman's name "opened doors magically" with the North Korean regime, referring to the warm reception of Vice's proposal of sending Rodman and other basketball players on a "goodwill" visit to the estranged state. ${ }^{121} \mathrm{At}$ the very least, this form of sport celebrity diplomacy has managed to gain direct access to the leader of one of the most secretive totalitarian states in the world, and opened (albeit a very limited) dialogue between Americans and the North Korean public. The reclusive and secretive North Korean regime has convinced many of its citizens, through mass-mediated propaganda, that the U.S. represents an evil military and cultural threat. Yet sports celebrity diplomacy, such as this "goodwill" visit can work to reduce perceived threats via sports and cultural attraction. Here, sports celebrity diplomacy may even serve as a subversive act in the DPRK. According to local media, the North Korean public was shocked to see KJU embracing Rodman, a tattooed and piercing-clad sports celebrity from America-a country the North Korean public have been taught to loathe and fear. ${ }^{122}$ Although we should not overestimate sports celebrity diplomacy as an effective instrument in bridging the divide between estranged states, neither should we underestimate how sport and celebrity athletes can be converted to soft power capital to attract and influence foreign publics. It is this attraction that can lead to greater dialogue and a thawing of relations between publics, even estranged ones.

\section{Conclusion}

Although recent revelations of torture, drone warfare, and intrusive surveillance activities have badly maligned the credibility of the U.S., citizens from around the world continue to follow, consume, and idealize U.S. cultural products, including sports. During his 2015 visit to Cuba, U.S. Congressman Charles Rangel noted that 
sports were atop a long list of things Cubans said they loved about America. It comes as no surprise that sports-via soccer, baseball and basketball-is being used as an early soft power resource to further thaw relations between the U.S. and Cuba-a historically hard power environment, now at the dawn of a new era of rapprochement. In June of 2015, the New York Cosmos soccer club became the first U.S. professional team to play in Cuba since 1978. In March 2016, President Obama capped his historic visit to Cuba with a baseball game between Major League Baseball's Tampa Bay Rays and the Cuban national baseball team-a symbolic "people-to-people" engagement centered on a sport that both countries share a common passion for.

Sports diplomacy via the celebrity athlete are a nascent and underutilized soft power resource worth further consideration to bridge dialogue and diplomatic relations between publics, including estranged nations and their heads of state. Public diplomacy efforts are marked by new economic challenges (e.g. China), and ideological challenges from militant Islam and rogue states such as North Korea. It is therefore a critical time to revisit the U.S.'s soft power currency in order to evaluate and utilize it effectively pursuant to legitimizing its actions and policies abroad, and to win the information war against both extremist groups like the Islamic State of Iraq and the Levant (ISIL) and the global public. With a vast array of cultural products encoded with American values and ideals, the U.S. possesses deep reserves in soft power, including the attraction of its global sports teams and celebrity athletes, which can influence international relations due to their universal appeal.

Although nations have employed sports diplomacy to bolster their image and brand, this essay explores the unique features of sports celebrities as an instrument of diplomacy. Furthermore, this essay expands Cooper and Vanc's work on celebrity diplomacy into the realm of celebrity athletes-as antidiplomats-with a case study that examined the attraction and value sports celebrity diplomacy can have toward fostering engagement within the most rigid, hard power environments. Finally, this work also underscores some of the major limitations that this soft power resource poses in the area of public diplomacy. Further research needs to explore how to measure and assess the efficacy of these sports diplomacy strategies for both statesponsored and private actor initiatives. Another valuable research inquiry could involve a comparative analysis on celebrity diplomats from the diverse fields of entertainment, including sports, music, film and television, in order to uncover if certain fields lends itself to greater credibility and attraction than others.

Bibliography

Abrahamian, Andray. "Inter-Korean rivalry takes the field." 38 North. Accessed January 5, 2016.

Andrews, David. L. Michael Jordan, Inc.: Corporate Sport, Media Culture, and Late Modern America. SUNY Press, 2001.

Andrews, David. L. and Steven J. Jackson. "Introduction: Sport Celebrities, Public Culture and Private Experience." In Sport Stars: The Cultural Politics of Sporting Celebrity, edited by David. L. Andrews and Steven. J. Jackson, 1-19. London: Routledge, 2002.

Badenhausen, Kurt. "Barcelona and Real Madrid Head the Most Popular Sports Teams on Social Media." Forbes. Accessed February 4, 2016.

Boorstin, Daniel. J. The Image: A Guide to Pseudo-Events in America. New York: Vintage Books, 2012. 
Bowden, Mark. "Understanding Kim Jong Un, the world's most enigmatic and unpredictable dictator." Vanity Fair. Accessed December 7, 2016.

Byrne, Brendan. "Kim Jong-un Wants North Korea in More Sports Events." ValueWalk. Accessed September 19, 2016.

Cha, Victor. The impossible state: North Korea, past and future. New York, NY: Harper Collins Publishers, 2012.

Chehabi, Houchang E. Sport diplomacy between the United States and Iran. Diplomacy and Statecraft, 12(1) (2001): 89-106.

Choe, Sang-Hun. “At Huge Rally, North Koreans Declare Kim their Leader." New York Times. Accessed March 17, 2016.

Choe, Sang-Hun. "Rodman Gives Details on Trip to North Korea." New York Times. Accessed March 17, 2016.

Choeng, Susan. "North Korea's Hearing-Impaired Football Team Given Rare Honour of Trip to Play Australia." ABC News. Accessed October 14, 2016.

Choi, Song Min. “Globetrotter Chic Shocks a Nation!” Daily NK. Accessed March 21, 2016.

Cooper, Andrew. F. Celebrity Diplomacy. Boulder: Paradigm Publishers, 2008.

Cowan, Geoffrey and Nicholas. J. Cull. "Public diplomacy in a changing world." The Annals of the American Academy of Political and Social Science, 616(1) (2008): 6-8.

Davis, Becky. "China Responds Well to Hardwood Ambassadors." The New York Times. Accessed November 4, 2016.

Demick, Barbara. "Dennis Rodman Talks North Korean Diplomacy Before an Audience of Cadets at West Point." Los Angeles Times. Accessed July 14, 2017.

“Dennis Rodman Makes 4th Trip to North Korea.” VOA News. Accessed July 14, 2016.

Dyer, Richard. Stars. London: BFI, 1979.

Evans, Gareth. J., and Bruce Grant. Australia's Foreign Relations in the World of the 1990s. Melbourne University Press, 1991.

"Ex-player of U.S. NBA Pay Respects to Kim Il Sung, Kim Jong Il." Korean Central News Agency. Accessed December 4, 2016.

Fan, Ying. "Soft Power: Power of Attraction or Confusion?" Place Branding and Public Diplomacy, 4(2) (2008): 147-158.

Fisher, Ali. "Four Seasons in One Day: The Crowded House of Public Diplomacy in the UK." Routledge Handbook of Public Diplomacy, New York, Routledge. (2009): 251-261.

Fisher, Max. "Kim Jong Eun Inherited an Eccentric Obsession with Basketball from Kim Jong Il." Washington Post. Accessed December 15, 2016.

Fischer, Paul. A Kim Jong-Il Production: The Extraordinary True Story of a Kidnapped Filmmaker, His Star Actress, and a Young Dictator's Rise to Power. New York, NY: Macmillan, 2015.

Fitts, R. K. “Murder, Espionage, and Baseball: The 1934 All American Tour of Japan.” NINE: A Journal of Baseball History and Culture, 21(1) (2012): 1-11.

“German-born Soccer Stars Choose to Play for U.S. National Team.” CNN. Accessed December 14, 2015. 
Gibson, Eric. “Why Dictators Love Kitsch.” Wall Street Journal. Accessed November 13, 2016. Grix, Jonathan and Barrie Houlihan. "Sports Mega-Events as Part of a Nation's Soft Power Strategy: The Cases of Germany (2006) and the UK (2012)." The British Journal of Politics \& International Relations, 16(4) (2014): 572-596.

Guilianotti, Richard and Roland Robertson. "Sport and Globalization." In A Companion to Sport, edited by David. L. Andrews and Ben Carrington, 41-60. New Jersey: Wiley-Blackwell Publishing, 2013.

Guttman, Allen. The Games Must Go On: Avery Brundage and the Olympic Movement. New York: Columbia University Press, 1984.

Hampson, Fen. O., and Dean F. Oliver. "Pulpit Diplomacy: A Critical Assessment of the Axworthy Doctrine.” International Journal, 53(3) (1998): 379-406.

Heil, Emily. “Cal Ripken to be Our Man in Japan.” Washington Post. Accessed October 14, 2016.

Higgins, Andrew. “Who Will Succeed Kim Jong-Il?” Washington Post. Accessed October 11, 2016.

Jackson, Steven. J. “The Contested Terrain of Sport Diplomacy in a Globalizing World." International Area Studies Review, 16(3) (2013): 274-284.

Jackson, Steven. J., and Stephen Haigh. Sport and Foreign Policy in a Globalizing World. Routledge, 2013.

Jorgenson, Jillian. "Rangel Touts Sports as Better for Diplomacy than Presidents." Observer News. Accessed October 15, 2016.

Kellner, Douglas. “The Sports Spectacle, Michael Jordan and Nike: Unholy Alliance.” In Michael Jordan, Inc.: Corporate Sport, Media Culture, and Late Modern America, edited by Douglas Kellner, 37-63. New York: State University of New York Press, 2001

Kessler, Glenn. "During Visit by Bill Clinton, North Korea Releases American Journalists." Washington Post. Accessed September 12, 2016.

"Kim Jong Un Meets Ex-NBA Star and His Party." Korean Central News Agency. Accessed December $2,2015$.

Koelbl, Susanne. “Advancing Globalization Makes its Mark in North Korea.” Der Spiegel Online. Accessed October 20, 2016.

LaFeber, Walter. (2002). Michael Jordan and the New Global Capitalism. New York: W. W. Norton \& Company, Inc., 2002.

Larmer, Brook. "The Center of the World.” Foreign Policy. Accessed October 15, 2016.

Manzenreiter, Wolfram. "The Beijing Games in the Western Imagination of China: The Weak Power of Soft Power." Journal of Sport \& Social Issues, 34(1) (2010): 29-48.

Mattern, Janice. B. “Why Soft Power isn't so Soft” In Power in World Politics, edited by Felix Berenskoetter and Michael. J. Williams, 98-119. New York, NY: Routledge, 2007.

McClintock, Pamela. “Boxoffice Milestone: ‘Transformers: Age of Extinction' Hits 1 Billion Worldwide." The Hollywood Reporter. Accessed October 15, 2016.

Merkel, Udo. "Flags, Feuds and Frictions: North Korea and the London 2012 Olympics." The International Journal of the History of Sport, 30(15) (2013): 1810-1822.

"Most Watched TV Show in the World is 'CSI: Crime Scene Investigation.”' Huffpost. Accessed September 12, 2016. 
Murray, Stuart. “The Two Halves of Sports-Diplomacy." Diplomacy \& Statecraft, 23(3) (2012): 576-592.

Murray, Stuart. "Moving Beyond the Ping-Pong Table: Sports Diplomacy in the Modern Diplomatic Environment.” Public Diplomacy Magazine, 9 (2013): 11-16.

Murray, Stuart and Geoffrey A. Pigman. "Mapping the Relationship Between International Sport and Diplomacy." Sport in Society, 17(9) (2014): 1098-1118.

Neuman, Scott. “Add “North Korea Expert' to Dennis Rodman's Resume.” NPR. Accessed October $15,2016$.

Nye, Joseph. S. "The Information Revolution and American Soft Power." Asia-Pacific Review, 9(1) (2002): 60-76.

Nye, Joseph. S. Soft Power: The Means to Success in World Politics. New York: Public Affairs, 2004.

Nye, Joseph. S. Understanding International Conflicts. New York: Pearson, 2008.

Nye, Joseph. S., and Wang Jisi. "Hard Decisions on Soft Power Opportunities and Difficulties for Chinese Soft Power." Harvard International Review, 31(2) (2009): 18.

Oberdorfer, Don and Robert Carlin. The Two Koreas: A Contemporary History. New York, NY: Basic Books, 2001.

Park, Kyung-Ae. “Can We Engage North Korean with Soft Power?" NK News. Accessed October 16, 2016.

Pigman, Geoffrey A. “'Crouch, Touch, Pause, Engage!': Moving Forward in the Scrum of International Sport and Public Diplomacy." Public Diplomacy Magazine 8(2012): 81-88.

Pigman, Geoffrey. A. “International Sport and Diplomacy's Public Dimension: Governments, Sporting Federations and the Global Audience.” Diplomacy \& Statecraft, 25(1) (2014): 94-114.

Potter, Evan. H. Branding Canada: Projecting Canada's Soft Power through Public Diplomacy. McGillQueen's Press-MQUP, 2008.

Price, Greg. "U.S. Military Presence in Asia: Troops Stationed in Japan, South Korea and Beyond." Newsweek. Accessed May 15, 2017.

"Prince William Scores with Football Diplomacy in China. Accessed November 20, 2015.

Redeker, Robert. "Sport as an Opiate of International Relations: The Myth and Illusion of Sport as a Tool of Foreign Diplomacy.” Sport in Society, 11(4) (2008): 494-500.

Roselle, L., Alister Miskimmon, and Ben O’Loughlin. “Strategic Narrative: A New Means to Understand Soft Power." Media, War \& Conflict, 7(1) (2014): 70-84.

Shearlaw, Maeve. "Dennis Rodman to Go Back to North Korea-Again." The Guardian. Accessed October 17, 2016.

Smart, Barry. The Sport Star-Modern Sport and the Cultural Economy of Sporting Celebrity. London: Sage Publications, 2005.

Thussu, Daya. “De-Americanizing Soft Power Discourse?” Public Diplomacy Magazine, April 2014.

Tsaliki, Liza, Christos A. Frangonikolopoulos, and Asteris Huliaras, eds. Transnational Celebrity Activism in Global Politics: Changing the World? Intellect Books, 2011.

U.S. Department of State. "U.S. Department of State and Major League Baseball and Softball 'Diamond Diplomacy." Accessed October 15, 2015. 
Vanc, Antoaneta. M. "The Counter-intuitive Value of Celebrity Athletes as Antidiplomats in Public Diplomacy: Ilie Nastase from Romania and the World of Tennis." Sport in Society, 17(9) (2014):1187-1203.

Wakin, Daniel. "North Koreans Welcome Symphonic Diplomacy.” New York Times. Accessed October 12, 2016.

Zeigler, Mark. “The Oddest Fan.” The San Diego Union Tribune. Accessed October 12, 2016.

\section{ENDNOTES}

1.

Guttman, The Games Must Go On, 195.

2. See Antoaneta. M. Vanc. "The Counter-intuitive Value of Celebrity Athletes as Antidiplomats in Public Diplomacy: Ilie Nastase from Romania and the World of Tennis." Sport in Society, 17(9) (2014):1187-1203; Murray, Stuart and Geoffrey A. Pigman. "Mapping the Relationship Between International Sport and Diplomacy." Sport in Society, 17(9) (2014): 1098-1118.

3. Evans and Grant, Australia's Foreign Relations, 66.

4. Geoffrey Cowan and Nicholas J. Cull. "Public diplomacy in a changing world." The Annals of the American Academy of Political and Social Science, 616(1) (2008): 6-8.

5. Vanc, "The Counter-intuitive Value of Celebrity Athletes," 1187.

6. Robert Redeker. "Sport as an Opiate of International Relations: The Myth and Illusion of Sport as a Tool of Foreign Diplomacy." Sport in Society, 11(4) (2008): 494-500.

7. Stuart Murray and Geoffrey A. Pigman. "Mapping the Relationship Between International Sport and Diplomacy." Sport in Society, 17(9) (2014): 1098-1118.

8. Steven J. Jackson. "The Contested Terrain of Sport Diplomacy in a Globalizing World." International Area Studies Review, 16(3) (2013): 274-284.

9. Jonathan Grix and Barrie Houlihan. "Sports Mega-Events as Part of a Nation's Soft Power Strategy: The Cases of Germany (2006) and the UK (2012)." The British Journal of Politics \& International Relations, 16(4) (2014): 572-596.

10. Joseph. S Nye. Soft Power: The Means to Success in World Politics. New York: Public Affairs, 2004.

11. Andrew F. Cooper. Celebrity Diplomacy. Boulder: Paradigm Publishers, 2008.

12. Vanc, "The Counter-intuitive Value of Celebrity Athletes."

13. Cha, The Impossible State, 252.

14. Sang-Hun Choe. "At Huge Rally, North Koreans Declare Kim their Leader." New York Times. Accessed March 17, 2016.

15. Merkel, "Flags, Feuds and Frictions," 1815.

16. Oberdorfer, The Two Koreas, 439.

17. See Max Fisher. "Kim Jong Eun Inherited an Eccentric Obsession with Basketball from Kim Jong Il.” Washington Post. Accessed December 15, 2016.

18. See Susanne Koelbl. “Advancing Globalization Makes its Mark in North Korea.” Der Spiegel Online. Accessed October 20, 2016.

19. Merkel, "Flags, Feuds and Frictions."

20. See Nye, Soft Power.

21. Nye, Understanding International Conflicts, 63. 
22. See Nye and Wang, "Hard Decisions on Soft Power."

23. See Fan, "Soft Power: Power of Attraction."

24. See Fan, "Soft Power: Power of Attraction."

25. Nye, Soft Power, 17.

26. See Nye, Soft Power.

27. Kyung-Ae Park. "Can We Engage North Korean with Soft Power?" NK News. Accessed October 16, 2016.

28. See Nye, Soft Power.

29. L.Roselle Alister Miskimmon and Ben O'Loughlin. "Strategic Narrative: A New Means to Understand Soft Power." Media, War \& Conflict, 7(1) (2014): 70-84.

30. Janice B. Mattern. "Why Soft Power isn't so Soft" In Power in World Politics, edited by Felix Berenskoetter and Michael. J. Williams, 98-119. New York, NY: Routledge, 2007.

31. Mattern, "Why Soft Power isn't so Soft."

32. See Nye, "The Information Revolution."

33. Jackson and Haigh, Sport and Foreign Policy, 4.

34. LaFeber, Michael Jordan and the New Global, 143.

35. Jillian Jorgenson. "Rangel Touts Sports as Better for Diplomacy than Presidents." Observer News. Accessed October 15, 2016.

36. Steven J Jackson. "The Contested Terrain of Sport Diplomacy in a Globalizing World." International Area Studies Review, 16(3) (2013): 274-284.

37. Redeker, "Sport as an Opiate," 495.

38. LaFeber, Michael Jordan and the New Global, 156.

39. LaFeber, Michael Jordan and the New Global, 110.

40. LaFeber, Michael Jordan and the New Global, 65-67.

41. LaFeber, Michael Jordan and the New Global, 68.

42. Kellner, "The Sports Spectacle," 37.

43. See David L Andrews. Michael Jordan, Inc.: Corporate Sport, Media Culture, and Late Modern America. SUNY Press, 2001; see also LaFeber, Michael Jordan and the New Global.

44. LaFeber, Michael Jordan and the New Global, 140.

45. LaFeber, Michael Jordan and the New Global, 142.

46. "Most Watched TV Show in the World is 'CSI: Crime Scene Investigation."' Huffpost. Accessed September 12, 2016.

47. Pamela McClintock. "Boxoffice Milestone: 'Transformers: Age of Extinction' Hits 1 Billion Worldwide." The Hollywood Reporter. Accessed October 15, 2016.

48. Becky Davis. "China Responds Well to Hardwood Ambassadors." The New York Times. Accessed November 4, 2016.

49. Becky. "China Responds Well."

50. Kurt Badenhausen. "Barcelona and Real Madrid Head the Most Popular Sports Teams on Social Media." Forbes. Accessed February 4, 2016.

51. Geoffrey Cowan and Nicholas. J. Cull. "Public diplomacy in a changing world." The Annals of the American Academy of Political and Social Science, 616(1) (2008): 6-8.

52. See Ali Fisher. "Four Seasons in One Day: The Crowded House of Public Diplomacy in the UK." Routledge Handbook of Public Diplomacy, New York, Routledge. (2009): 251-261.

53. Stuart Murray and Geoffrey A. Pigman. "Mapping the Relationship Between International Sport and Diplomacy." Sport in Society, 17(9) (2014): 1098-1118.

54. Murray, "The Two Halves of Sports-Diplomacy," 581.

55. Murray, "The Two Halves of Sports-Diplomacy," 581.

56. Redeker, "Sport as an Opiate," 496.

57. U.S. Department of State. "U.S. Department of State and Major League Baseball and Softball 'Diamond Diplomacy.”' Accessed October 15, 2015. 
58. See Grix and Houlihan, "Sports Mega-Events."

59. Larmer, "The Center of the World," 69.

60. Andray Abrahamian. "Inter-Korean rivalry takes the field." 38 North. Accessed January 5, 2016. http://38north.org/2014/10/aabrahamian100614/.

61. Murray and Pigman, "Mapping the Relationship," 1106.

62. Murray and Pigman, "Mapping the Relationship."

63. Murray and Pigman, "Mapping the Relationship."

64. Murray and Pigman, "Mapping the Relationship."

65. Murray and Pigman, "Mapping the Relationship."

66. Guilianotti and Robertson. "Sport and Globalization," 51.

67. Miskimmon Roselle and Ben O'Loughlin, "Strategic Narrative," 74.

68. "German-born Soccer Stars Choose to Play for U.S. National Team." CNN. Accessed December 14, 2015.

69. "German-born Soccer Stars Choose to Play for U.S. National Team." CNN.

70. Jackson, "The Contested Terrain of Sport," 1.

71. Manzenreiter, "The Beijing Games," 31.

72. Fitts, "Murder, Espionage, and Baseball," 8-9.

73. Fitts, "Murder, Espionage, and Baseball," 9.

74. Fitts, "Murder, Espionage, and Baseball," 9.

75. "Prince William Scores with Football Diplomacy in China. The Daily Mail Online. Accessed November 20, 2015.

76. See Dyer, Stars.

77. Daniel J. Boorstin. The Image: A Guide to Pseudo-Events in America. New York: Vintage Books, 2012.

78. Boorstin, The Image, 57.

79. Murray, "The Two Halves of Sports-Diplomacy," 579.

80. Cooper, Celebrity Diplomacy, 7.

81. Cooper, Celebrity Diplomacy, 3.

82. Cooper, Celebrity Diplomacy, 7.

83. Fen. O.Hampson and Dean F. Oliver. "Pulpit Diplomacy: A Critical Assessment of the Axworthy Doctrine.” International Journal, 53(3) (1998): 379-406; Potter, Evan. H. Branding Canada: Projecting Canada's Soft Power through Public Diplomacy. McGill-Queen's Press-MQUP, 2008.

84. Murray, "The Two Halves of Sports-Diplomacy," 579.

85. Cooper, Celebrity Diplomacy, 2.

86. Cooper, Celebrity Diplomacy, 7.

87. Cooper, Celebrity Diplomacy, 2.

88. Cooper, Celebrity Diplomacy, 4.

89. See Cooper, Celebrity Diplomacy and Tsaliki, Frangonikolopoulos, and Huliaras, Transnational Celebrity Activism.

90. Pigman, "Crouch, Touch, Pause, Engage!," 86.

91. Andrews, and Jackson, "Introduction: Sport Celebrities, Public Culture," 8.

92. Vanc, "The Counter-intuitive Value," 1191.

93. Boorstin, The Image.

94. Redeker, "Sport as an Opiate," 499.

95. Cooper, Celebrity Diplomacy, 53-54.

96. See Cooper, Celebrity Diplomacy.

97. Vanc, "The Counter-intuitive Value," 1201.

98. Vanc, "The Counter-intuitive Value."

99. Vanc, "The Counter-intuitive Value." 
100. Maeve Shearlaw. "Dennis Rodman to Go Back to North Korea-Again.” The Guardian. Accessed October 17, 2016.

101. Sang-Hun Choe. "Rodman Gives Details on Trip to North Korea." New York Times. Accessed March 17, 2016.

102. "Dennis Rodman Makes 4th Trip to North Korea." VOA News. Accessed July 14, 2016.

103. Demick, Barbara. "Dennis Rodman Talks North Korean Diplomacy Before an Audience of Cadets at West Point." Los Angeles Times. Accessed July 14, 2017.

104. Jackson, "The Contested Terrain," 277.

105. Scott Neuman. “Add 'North Korea Expert' to Dennis Rodman's Resume." NPR. Accessed October 15, 2016.

106. Scott. “Add 'North Korea Expert'

107. Fischer, A Kim Jong-Il Production, 38.

108. See Fischer, A Kim Jong-Il Production.

109. See Fischer, A Kim Jong-Il Production.

110. Mark Zeigler. "The Oddest Fan.” The San Diego Union Tribune. Accessed October 12, 2016.

111. Zeigler, "The Oddest Fan."

112. See Higgins, "Who Will Succeed Kim Jong-Il?"

113. Daniel Wakin. "North Koreans Welcome Symphonic Diplomacy." New York Times. Accessed October 12, 2016.

114. Brendan Byrne. "Kim Jong-un Wants North Korea in More Sports Events." ValueWalk. Accessed September 19, 2016.

115. Susan Choeng. "North Korea's Hearing-Impaired Football Team Given Rare Honour of Trip to Play Australia." ABC News. Accessed October 14, 2016.

116. See Kellner, "The Sports Spectacle."

117. Eric Gibson. "Why Dictators Love Kitsch." Wall Street Journal. Accessed November 13, 2016.

118. Glenn Kessler. "During Visit by Bill Clinton, North Korea Releases American Journalists." Washington Post. Accessed September 12, 2016.

119. "Ex-player of U.S. NBA Pay Respects to Kim Il Sung, Kim Jong Il." Korean Central News Agency. Accessed December 4, 2016.

120. "Kim Jong Un Meets Ex-NBA Star and His Party." Korean Central News Agency. Accessed December 2, 2015.

121. Mark Bowden. "Understanding Kim Jong Un, the world's most enigmatic and unpredictable dictator." Vanity Fair. Accessed December 7, 2016.

122. Song Min Choi. “Globetrotter Chic Shocks a Nation!” Daily NK. Accessed March 21, 2016.

\section{ABSTRACTS}

This paper seeks to explore some of the unique features of sport as an instrument of American soft power. Informed by Cooper's theoretical perspective on celebrity diplomacy, this work extends the celebrity diplomacy discourse into the area of sports celebrities and explores the unique features of celebrity athletes as an instrument of diplomacy. This work also expands the discourse on celebrity athletes as non-state sanctioned antidiplomats, and examines Dennis Rodman's "basketball diplomacy" efforts in North Korea as a case study to examine the power celebrity athletes can have-contrary to what one would expect-toward fostering engagement with even the most reclusive and hostile governments. Moreover, this works examines North Korean media accounts of Rodman's basketball diplomacy, in order to evaluate the potential limitations of celebrity athlete diplomacy and to offer cautious conclusions when celebrity athletes are used as instruments of engagement. 
INDEX

Keywords: Sports communication, celebrity diplomacy, sports diplomacy, soft power, sports celebrity diplomacy

\section{AUTHOR}

\section{MICHAEL K. PARK}

Michael K. Park specializes in media law, communications policy and sports communication. Moreover, his research interests include critical media studies, race and masculinity and public diplomacy. Park's writing has appeared in communication and law journals. His professional experience includes stints at William Morris Endeavor, in Beverly Hills, California, where he worked in the Motion Picture department and the Federal Communications Commission, in the office of FCC Commissioner Michael J. Copps. Park recently completed his doctorate at the Annenberg School for Communication and Journalism at the University of Southern California and is also a graduate of the University of California, Hastings College of the Law. 